\title{
COMPARISON OF THE EFFECTS OF WEB-BASED AND FACE-TO-FACE TRAINING ON THE SELF-EFFICACY AND HEALTH LITERACY OF PATIENTS WITH HYPERTENSION: A QUASI-EXPERIMENTAL TRIAL
}

\author{
Hipertansiyon hastalarına verilen web tabanlı ve yüz yüze eğitimin özetkililik ve \\ sağlık okuryazarlığına etkisinin karşılaştırılması-yarı deneysel bir çalışma
}

\author{
Nihan TÜRKOĞLU1 ${ }^{(i)}$, Dilek KILIÇ ${ }^{\text {iD }}$
}

\begin{abstract}
This study aimed to compare the effects of web-based and face-to-face patient education on the self-efficacy and health literacy of patients with hypertension. A prospective, quasi-experimental trial was conducted in Eastern Turkey. Hypertension patients were into two groups: a web-based group $(n=70)$ and a face-to-face group $(n=66)$. The participants' demographics were collected with the Descriptive Characteristics Form, and the participants' scores on the Health Literacy Scale and the Hypertension Self-Efficacy Scale were measured before and after the training. The mean Health Literacy Scale and Hypertension Self-Efficacy Scale scores of the participants in the web training group and those in the face-to-face training group both increased in the posttests compared to the pretests $(p<0.001)$. There was no statistically significant difference between the groups according to the type of education ( $p>0.05)$. Both web-based and face-to-face training for patients with hypertension had a positive effect on health literacy and self-efficacy levels, with no difference between the two training methods.
\end{abstract}

Keywords: Face-to-face training, health literacy, hypertension, self-efficacy, web training.

Özet

Bu çalışma; hipertansiyon hastalarına verilen web tabanlı ve yüz yüze eğitimin öz-etkililik ve sağlık okuryazarlığına etkisinin karşılaştırılması amacıyla yapılmıştır. Türkiye'nin doğusunda bir bölgede yapılan çalışma, yarı deneysel düzende yapılmıştır. Hipertansiyon hastaları web tabanlı ve yüz yüze eğitim grubu olmak üzere ikiye ayrılmıştır. Katılımcıların demografik özellikleri Tanımlayıcı Özellikler Formu kullanılarak toplandı. Ayrıca eğitim öncesi ve sonrasında katılımcılara Sağlık Okuryazarlığı Ölçeği ve Hipertansiyon Öz-Yeterlik Ölçeği uygulanarak puan ortalamalarına bakıldı. Web eğitim grubundaki ve yüz yüze eğitim grubundaki katılımcıların Sağlık Okuryazarlığı Ölçeği ve Hipertansiyon Öz-Yeterlik Ölçeği puan ortalamaları ön testlere göre son testlerde artmıştır $(p<0,001)$. Eğitim türüne göre gruplar arasında istatistiksel olarak anlamlı fark saptanmamıştır $(p>0,05)$. Hipertansiyonlu hastalara verilen web tabanlı ve yüz yüze eğitim arasında bir fark bulunmazken, her iki eğitim yönteminin sağlık okuryazarlığı ve öz-yeterlik düzeyleri üzerinde olumlu bir etkiye sahip olduğu saptanmıştır.

Anahtar kelimeler: Yüz yüze eğitim, sağlık okuryazarlığı, hipertansiyon, öz-etkililik, web tabanlı eğitim.

1- Department of Public Health Nursing, Nursing Faculty, Ataturk University, Erzurum, Turkey

2- Department of Nursing, Nursing Faculty, Ataturk University, Erzurum, Turkey

Sorumlu Yazar / Corresponding Author: Asst. Prof. Dr. Nihan TÜRKOĞLU

e-posta / e-mail: nihan-25-kilic@hotmail.com

Geliş Tarihi / Received: 19.04.2021, Kabul Tarihi / Accepted: 31.07.2021

ORCID: Nihan TÜRKOĞLU

0000-0002-5843-9097

Dilek KILIÇ

:0000-0003-1799-2475

Nasıl Atıf Yaparım / How to Cite: Turkoglu N, Kılıc D. Comparison of the effects of web-based and face-to-face training on the self-efficacy and health literacy of patients with hypertension: a quasi-experimental trial. ESTUDAM Public Health Journal. 2022;7(1):15-25. 


\section{Introduction}

Hypertension is a serious medical condition that can increase the risk of heart, brain, kidney, and other diseases. It is a major cause of premature death worldwide, with upwards of 1 in 4 men and 1 in 5 women-over a billion people-having the condition (1). The prevalence, awareness, treatment and control of hypertension in Turkey study (PatenT) reported that hypertension is a very common health problem in Turkey and is not fully treated. According to the PatenT study, the prevalence of hypertension in the population over 18 years of age is $30.3 \%$ (2). It is also an illness with a low level of awareness despite the fact that it is frequently observed and increases proportionally with age.

The sense of self-efficacy is an important step in the initiation and maintenance of health initiatives. Self-efficacy perception is not only crucial to promote positive health behaviors in healthy people but also important for health protection, maintenance, and improvement in people with chronic illnesses. The self-efficacy perception is useful in many health behaviors, such as weight control, exercise, smoking, and alcohol abstinence and also of great importance in the management of chronic diseases, such as hypertension $(3,4)$. The sense of self-efficacy plays a vital role when people decide what to do and what not to do when determining their activities. As individuals' self-efficacy level increases in any subject, they will be more persistent and powerful in their activities (5). Increasing the level of self-efficacy of an individual causes him/her to exhibit positive health behaviors (3).

To raise awareness about hypertension, health literacy levels need to be raised (1). Improved health literacy will play a major role in improving patients' health care responsibility and self-efficacy. Health literacy ensures that appropriate services and information are attained, that resources are used correctly, that patients are able to use services, that quality conditions in health care are established, and that individuals are strengthened in relation to their own health and the health of the community. Increasing health literacy promotes preventive health services and improves people's quality of life by reducing treatment processes, resulting in decreased health care costs and thus contributing to a country's economy (6). Studies have reported that health literacy is up-to-date and needs to be improved $(7,8)$. For this purpose, the health literacy level in relation to chronic illnesses should be increased in society $(9,10)$. To increase the level of health literacy and raise the awareness of patients with hypertension, it is necessary to train them with different education methods.

Rapid advances in educational technology have enabled the addition of computer-based and web-based patient education to face-to-face methods. The initiation and maintenance of educational programs for health literacy in relation to chronic illnesses using web-based and face-to-face training methods will enable both the development of health literacy and the comparison of different education methods.

\section{Objectives:}

1.The aim of this study was to compare the effects of web-based and face-to-face training for hypertension patients on their self-efficacy and health literacy. In this study, three hypotheses were advanced:

2.Web-based education given to hypertensive patients increases the level of health literacy and self-efficacy.

3.Face-to-face education given to hypertensive patients increases the level of health literacy and self-efficacy.

4. There is no difference between the training methods given to hypertensive patients in the web and face-to-face training group. 


\section{Material-Method}

Study design: This study was a prospective, quasi-experimental trial conducted at a family health center in Eastern Turkey between January 2015 and June 2016.

Participants: The study was conducted with
136 hypertension patients, of whom 70 were in the web-based education group and 66 were in the face-to-face group. The study flow diagram for the enrollment of the hypertension patients is shown in Figure 1.

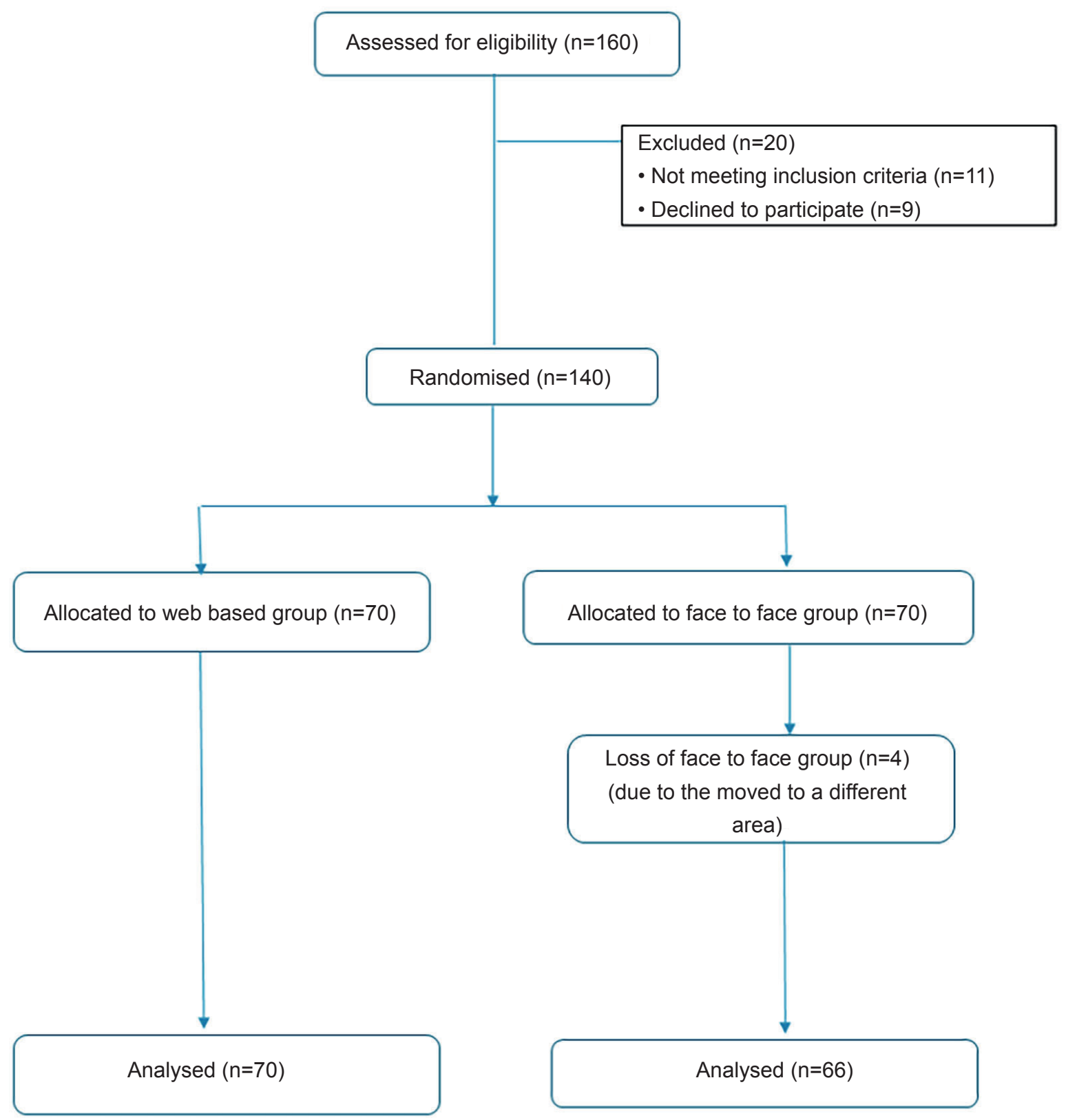

Figure 1: Flow of study. 
Data sources/measurement: The participants' data were collected by the researchers using the Descriptive Characteristics Form, the Health Literacy Scale, and the Hypertension Self-Efficacy Scale.

Descriptive Characteristics Form: This form consists of 10 questions that determine the socio-demographic characteristics of patients, 9 questions about reading habits, and 7 questions on the patient's disease.

Health Literacy Scale: The Health Literacy Scale (HLS) was developed by Suka et al. (2013) to measure adults' health literacy levels (11). The 14-item scale includes three sub-dimensions: functional health literacy, interactive health literacy, and critical health literacy. The five-point Likert-type scale is composed of 14 items where $1=$ strongly disagree and $5=$ strongly agree with scores for each question between one and five points. 1-5. Items are reverse coded. A minimum of 14 and a maximum of 70 points can be obtained from the scale. A higher total score indicates an increased level of patient health literacy. The validity and reliability study of the scale in Turkish was conducted by Türkoğlu and Kılıç (2021), who found the Cronbach's alpha value to be 0.82 (12). Furthermore, the Cronbach's alpha value was found to be 0.85 in this study.

Hypertension Self-Efficacy Scale: The Hypertension Self-Efficacy Scale was developed by Han et al. (2013) to determine the self-efficacy levels of hypertensive patients (13). The four-point Likert-type scale is composed of 20 items where $1=$ not at all appropriate and $4=$ very appropriate with scores for each question between one and four points. A minimum of 20 and a maximum of 80 points can be obtained from the scale. A higher total score indicates an increased level of patient self-efficacy. The validity and reliability study of the scale in Turkish was conducted by Türkoğlu and Kılıç (2015), who found that the Cronbach's alpha value of the scale was 0.88 (14). Furthermore, the Cronbach's alpha value was found to be 0.95 in this study.
Study size: The study participants were 1226 hypertensive patients registered with the family health center between January 2015 and June 2016 in Erzurum. The sample size was calculated using the Java Applets Power and Sample Size calculation program. The power of the study was determined to be $95 \%$ with an effect size of 0.92 (large) at a confidence interval of $95 \%$ and a significance level of 0.05 for the t-test analysis (15). According to the sample size calculation, the number of hypertension patients in the groups (140) was sufficient. Four individuals from the face-to-face training group were excluded from the study because they moved to a different area.

The inclusion criteria were as follows: aged 30-65 years old, graduated from at least primary school, having been diagnosed with hypertension for at least one year, being open to communication and willing to participate, able to use a computer, and not having a physical and mental illness which prevented participation in the study. Informed written consent was obtained from the patients with hypertension included in the study.

Interventions and Procedures: The pretest research data were collected via face-to-face interviews.

The face-to-face education group was trained a total of six times at two-week intervals. An education program was offered to participants in the web education group via the prepared website. A total of six trainings were uploaded to the web education group on the website.

For the participants in the face-to-face education group, the one-to-one education method, one of the most effective health education methods, was administered. Narration, questions and answers, demonstrations, and applications, which are some of the teaching methods in one-to-one education according to the relevant literature, were implemented (16). Six main topics were analyzed, and the program was conducted biweekly for three months. 
For the web education group, the researcher designed a website named "hipertansiyonlayasam.com". The website content integrated educational contexts, videos, posts, surveys, frequently asked questions, and contact links. It was checked whether the participants entered the website or not. Participants who did not enter the website were reminded by sending e-mail or message. On the website for participants in the web education group, six training modules were provided every two weeks.

The following are the topics of education given to the web education group and face-to-face education group.

1.Education: Definition of hypertension, its importance, symptoms, and reasons were explained.

2. Education: Risk factors of hypertension and damage to organs were explained.

3. Education: Blood pressure measurement at home was explained.

4. Education: Hypertension treatment and nutrition were explained.

5.Education: Exercise and other lifestyle behaviours in hypertension were explained.

6. Education: The topics discussed previously were summarized and the points

\section{Results}

The demographic characteristics are summarized in Table 1 . In the web-based training group, $74.3 \%$ of the patients were male, and $45.7 \%$ were in the age group of 30-40 years. In the face-to-face training group, $75.8 \%$ of the patients were of interest that were not understood were reviewed again by using the question-and-answer method.

Statistical methods: Statistical analyses were performed using the Statistical Package for the Social Sciences software program for Windows (version 20.0) (SPSS Inc., Chicago, IL, USA). Descriptive statistics are expressed as percentages, means, and standard deviations. The web-based and face-to-face groups were compared by the chi-square test, the independent t-test and paired sample t-test. A p-value $<0.05$ was considered statistically significant. In this study, it was determined whether the groups showed a normal distribution or not. Skewness and Kurtosis values were checked for normality test.

Ethics statement: This study was approved by the Atatürk University of Faculty of Health Sciences ethic committee (10.10.2013). No informed consent forms were collected, but the participants were clearly informed of the purpose of this study and were not pressured to participate in any way. Therefore, there were no disadvantages to non-participation.

Table 1: Socio-demographic characteristics of patients with hypertension.

\begin{tabular}{|c|c|c|c|c|c|}
\hline \multirow{2}{*}{ Variables } & \multicolumn{2}{|c|}{$\begin{array}{c}\text { Web-Based } \\
(n=70)\end{array}$} & \multicolumn{2}{|c|}{$\begin{array}{l}\text { Face to Face } \\
\quad(n=66)\end{array}$} & \multirow{2}{*}{$\begin{array}{c}\text { Test and } \\
\text { Significance }\end{array}$} \\
\hline & $s$ & $\%$ & $S$ & $\%$ & \\
\hline \multicolumn{6}{|l|}{ Gender } \\
\hline Female & 18 & 25.7 & 16 & 24.2 & $X^{2}=0.039$ \\
\hline Male & 52 & 74.3 & 50 & 75.8 & $p=0.843$ \\
\hline \multicolumn{6}{|l|}{ Age } \\
\hline $30-40$ & 32 & 45.7 & 22 & 33.3 & \\
\hline $41-50$ & 18 & 25.7 & 17 & 25.8 & $X^{2}=5.034$ \\
\hline $51-60$ & 16 & 22.9 & 16 & 24.2 & $\mathrm{p}=0.169$ \\
\hline $61-65$ & 4 & 5.7 & 11 & 16.7 & \\
\hline
\end{tabular}




\begin{tabular}{|c|c|c|c|c|c|}
\hline \multicolumn{6}{|l|}{ Education } \\
\hline Primary school & 18 & 25.7 & 25 & 37.9 & \multirow{3}{*}{$\begin{array}{c}X^{2}=2.325 \\
p=0.313\end{array}$} \\
\hline High school & 38 & 54.3 & 30 & 45.4 & \\
\hline University and over & 14 & 20.0 & 11 & 16.7 & \\
\hline \multicolumn{6}{|l|}{ Marital Status } \\
\hline Married & 64 & 91.4 & 61 & 92.4 & \multirow{2}{*}{$\begin{array}{c}X^{2}=0.045 \\
p=0.831\end{array}$} \\
\hline Single & 6 & 8.6 & 5 & 7.6 & \\
\hline \multicolumn{6}{|l|}{ Employment Status } \\
\hline Employed & 45 & 64.3 & 35 & 53.0 & \multirow{2}{*}{$\begin{array}{l}X^{2}=1.777 \\
p=0.183\end{array}$} \\
\hline Unemployed & 25 & 35.7 & 31 & 47.0 & \\
\hline \multicolumn{6}{|l|}{ Reading Status } \\
\hline Read & 47 & 67.1 & 36 & 54.5 & \multirow{2}{*}{$\begin{array}{l}X^{2}=2.267 \\
p=0.132\end{array}$} \\
\hline Not read & 23 & 32.9 & 30 & 45.5 & \\
\hline \multicolumn{6}{|l|}{ Reading Level } \\
\hline Excellent & 8 & 11.4 & 5 & 7.6 & \multirow{5}{*}{$\begin{array}{c}X^{2}=6.952 \\
p=0.138\end{array}$} \\
\hline Very good & 2 & 2.9 & 6 & 9.1 & \\
\hline Good & 33 & 47.1 & 25 & 37.9 & \\
\hline Bad & 18 & 25.7 & 13 & 19.7 & \\
\hline Very bad & 9 & 12.9 & 17 & 25.7 & \\
\hline Average Values & $\bar{x}$ & SD & $\bar{x}$ & SD & \\
\hline Systolic blood pressure & 153.14 & 23.71 & 147.50 & 22.45 & $\begin{array}{l}t=0.873 \\
p=0.157\end{array}$ \\
\hline Diastolic blood pressure & 86.64 & 11.47 & 85.00 & 10.11 & $\begin{array}{l}t=0.513 \\
p=0.378\end{array}$ \\
\hline
\end{tabular}

SD: Standard Deviation

Among the participants in the web and the face-to-face education groups, the pretest mean scores of the HLS, the Hypertension Self-Efficacy Scale were compared. Among the individuals in both groups, all the measurement tool scores were identical and medium-level $(p>0.05)$ (Table 2).

Table 2: Comparing pre-test mean scores of HLS and Hypertension Self-Efficacy Scale of the web-based and face-to-face training groups.

\begin{tabular}{|c|c|c|c|c|}
\hline \multirow{6}{*}{ 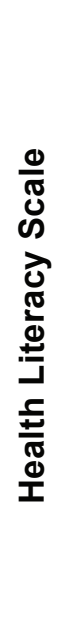 } & Scale and Subscales & $\begin{array}{c}\text { Web-Based } \\
\bar{X} \pm S D\end{array}$ & $\begin{array}{c}\text { Face to Face } \\
\bar{X} \pm S D\end{array}$ & $\begin{array}{c}\text { Test and } \\
\text { Significance }\end{array}$ \\
\hline & Functional HL & $14.17 \pm 9.05$ & $12.84 \pm 8.59$ & $\begin{array}{l}t=0.873 \\
p=0.384\end{array}$ \\
\hline & Communicative $\mathrm{HL}$ & $17.17 \pm 7.91$ & $18.24 \pm 7.82$ & $\begin{array}{l}t=-0.793 \\
p=0.429\end{array}$ \\
\hline & Critic HL & $13.22 \pm 6.29$ & $15.16 \pm 5.61$ & $\begin{array}{l}t=-1.891 \\
p=0.061\end{array}$ \\
\hline & HLS Total Score & $44.57 \pm 11.60$ & $44.60 \pm 10.63$ & $\begin{array}{l}t=-1.011 \\
p=0.314\end{array}$ \\
\hline & Hypertension Self Efficacy Scale & $42.61 \pm 18.10$ & $37.30 \pm 17.15$ & $\begin{array}{l}t=1.754 \\
p=0.082\end{array}$ \\
\hline
\end{tabular}


The scores for the web-based training group are shown in Table 3, and the scores for the face-to-face training group are shown in Table 4. The HLS pretest average score of the web-based training group was $44.57 \pm 11.60$, and the posttest average score was $57.54 \pm 5.48$ (Table 3 ).
The HLS pretest average score of the face-to-face training group was $46.25 \pm 7.20$, and the posttest average score was $59.25 \pm 5.17$ (Table 4). The difference between the mean scores of the groups was found to be statistically significant $(p<0.001)$.

Table 3: Pre-test and post-test mean scores of HLS and Hypertension Self-Efficacy Scale of the Web-Based Education Group.

\begin{tabular}{|c|c|c|c|c|}
\hline \multirow{2}{*}{\multicolumn{2}{|c|}{ Scale and Subscales }} & \multicolumn{2}{|c|}{ Web-Based } & \multirow[b]{2}{*}{$\begin{array}{c}\text { Test }^{*} \text { and } \\
\text { Significance }\end{array}$} \\
\hline & & $\begin{array}{l}\text { Pre-test } \\
\bar{X} \pm S D\end{array}$ & $\begin{array}{c}\text { Post- test } \\
\bar{X} \pm S D\end{array}$ & \\
\hline \multirow{5}{*}{ 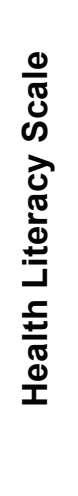 } & Functional $\mathrm{HL}$ & $14.17 \pm 9.05$ & $18.02 \pm 5.33$ & $\begin{array}{l}t=-3.070 \\
p<0.001\end{array}$ \\
\hline & Communicative HL & $17.17 \pm 7.91$ & $22.74 \pm 3.31$ & $\begin{array}{l}t=-6.387 \\
p<0.001\end{array}$ \\
\hline & Critic HL & $13.22 \pm 6.29$ & $16.74 \pm 3.01$ & $\begin{array}{l}t=-4.218 \\
p<0.001\end{array}$ \\
\hline & HLS Total Score & $44.57 \pm 11.60$ & $57.54 \pm 5.48$ & $\begin{array}{l}t=-9.835 \\
p<0.001\end{array}$ \\
\hline & Hypertension Self Efficacy Scale & $42.61 \pm 18.10$ & $57.90 \pm 14.74$ & $\begin{array}{l}t=-5.784 \\
p<0.001\end{array}$ \\
\hline
\end{tabular}

${ }^{*}$ Paired Sample t-Test

The Hypertension Self-Efficacy Scale pretest average total score of the web-based training group was $42.61 \pm 18.10$, and the posttest score average was $57.90 \pm 14.74$ (Table 3). For the face-to-face training group, the Hypertension Self-Efficacy Scale pretest total score average was $37.30 \pm 17.15$, and the posttest score average was $59.36 \pm 12.29$ (Table 4). The difference between the mean scores of the groups was statistically significant $(p<0.001)$.

Table 4: Pre-test and post-test mean scores of HLS and Hypertension Self-Efficacy Scale of the Face-To-Face Education Group.

\begin{tabular}{|c|c|c|c|c|}
\hline \multirow{2}{*}{\multicolumn{2}{|c|}{ Scale and Subscales }} & \multicolumn{2}{|c|}{ Face to Face } & \multirow[b]{2}{*}{$\begin{array}{l}\text { Test* and } \\
\text { Significance }\end{array}$} \\
\hline & & $\begin{array}{l}\text { Pre-test } \\
\bar{X} \pm S D\end{array}$ & $\begin{array}{c}\text { Post- test } \\
\bar{X} \pm S D\end{array}$ & \\
\hline \multirow{5}{*}{ 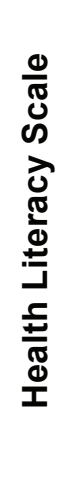 } & Functional HL & $12.84 \pm 8.59$ & $19.63 \pm 4.69$ & $\begin{array}{l}t=-5.949 \\
p<0.001\end{array}$ \\
\hline & Communicative HL & $18.24 \pm 7.82$ & $22.01 \pm 3.76$ & $\begin{array}{l}t=-3.835 \\
p<0.001\end{array}$ \\
\hline & Critic HL & $15.16 \pm 5.61$ & $17.61 \pm 3.13$ & $\begin{array}{l}t=-3.093 \\
p<0.001\end{array}$ \\
\hline & HLS Total Score & $46.25 \pm 7.20$ & $59.25 \pm 5.17$ & $\begin{array}{l}t=-17.998 \\
p<0.001\end{array}$ \\
\hline & Hypertension Self Efficacy Scale & $37.30 \pm 17.15$ & $59.36 \pm 12.29$ & $\begin{array}{l}t=-9.511 \\
p<0.001\end{array}$ \\
\hline
\end{tabular}

${ }^{*}$ Paired Sample t-Test, SD: Standard Deviation 
The mean HLS posttest score was $57.54 \pm 5.48$ in the web-based training group and $59.25 \pm 5.17$ in the face-to-face training group (Table 5).

Table 5: Comparing post-test mean scores of HLS and Hypertension Self-Efficacy Scale of the web-based and Face-To-Face Training Groups.

\begin{tabular}{|c|c|c|c|c|}
\hline \multirow{6}{*}{ 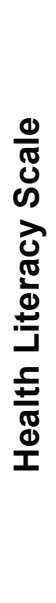 } & Scale and Subscales & $\begin{array}{c}\text { Web-Based } \\
\bar{X} \pm S D\end{array}$ & $\begin{array}{c}\text { Face to Face } \\
\bar{X} \pm S D\end{array}$ & $\begin{array}{c}\text { Test and } \\
\text { Significance }\end{array}$ \\
\hline & Functional $\mathrm{HL}$ & $18.02 \pm 5.33$ & $19.63 \pm 4.69$ & $\begin{array}{l}t=-1.860 \\
p=0.065\end{array}$ \\
\hline & Communicative $\mathrm{HL}$ & $22.74 \pm 3.31$ & $22.01 \pm 3.76$ & $\begin{array}{l}t=1.198 \\
p=0.233\end{array}$ \\
\hline & Critic HL & $16.74 \pm 3.00$ & $17.61 \pm 3.13$ & $\begin{array}{l}t=-1.639 \\
p=0.104\end{array}$ \\
\hline & HLS Total Score & $57.54 \pm 5.48$ & $59.25 \pm 5.17$ & $\begin{array}{l}t=-0.159 \\
p=0.874\end{array}$ \\
\hline & Hypertension Self Efficacy Scale & $57.90 \pm 14.74$ & $59.36 \pm 12.29$ & $\begin{array}{l}t=-0.627 \\
p=0.532\end{array}$ \\
\hline
\end{tabular}

SD: Standard Deviation

\section{Discussion}

The findings of this study show that web-based education of hypertension patients is equally effective as face-to-face education. This study demonstrated that regardless of the provided education method, the health literacy mean score of all hypertension patients rose following the training. This result is in line with previous studies (17-19). Several studies have found that a health literacy-based education program could elevate participants' health literacy. For example, Altsitsiadis et al. (2012) reported that as health literacy increased, there was a corresponding rise in taking sun protection measures against skin cancer risk (20). Cho et al. (2008) detected that as health literacy rose, there was a surge in using preventive services (21), while Pagan et al. (2012) found in that women with satisfactory health literacy levels had higher rates of mammography screening in the last two weeks (22).

In this study, the posttest mean scores for self-efficacy levels were significantly higher in both the web-based education and the face-to-face education groups. Previous studies have emphasized the necessity of self-efficacy perception to initiate and sustain positive health behaviors. Kim et al. (2012) detected that after receiving training, hypertension patients' self-efficacy levels increased (7). Similarly, in a quasi-experimental study that investigated the effect of training provided to diabetic patients on their self-efficacy levels, the patients' self-efficacy levels rose after the training (23). In the same way, in a study by Rader et al. (2017) that analyzed the self-efficacy $f$ obesity treatment for women (3), following the planned education program intervention and a one-year period of observation, there was a surge in the subject's self-efficacy/competency level. In research on self-efficacy, it has been determined that training creates a positive change in patients' self-efficacy perceptions $(24,25)$. Since self-efficacy perception was higher in the posttest scores in our study, it is safe to argue that irrespective of the provided education method, all patients receiving the training were better at managing their hypertension in due course.

With respect to the pretest and posttest mean scores of the hypertension patients' Health literacy levels in our study, there was a significant jump in both the 
web-based and the face-to-face education groups. In a study conducted by nurses in Korea, the effectiveness of a website designed to measure the health behaviors of patients and families to prevent a secondary stroke in patients who had had one before was analyzed. The control group that received no education, the test group that received web-based education, and the group that received information booklets were compared. In the assessment that took place 12 weeks later, both patients' and their families' adaptation to health behaviors was measured to be significantly higher in the groups receiving web-based and booklet education compared to the control group (26). In a study analyzing hypertension patients' medicine use, there was a rise in the knowledge level of disease management and medicine use among patients who were trained on their diseases and medicine use (27). Wei et al. (2019) ascertained in their study that web-based education initiated a climb in the knowledge level of diabetic patients (28).

In a study conducted among nursing students, no significant difference was observed between web-based and face-to-face education groups (29). Similarly, a study designed in Solomon's four-group

\section{Conclusion}

The evidence from previous studies has shown that both web-based and face-to-face education methods provide many benefits from a myriad of aspects. Similarly, in our study, the effectiveness of both education methods was proven, and in both education groups, the mean scores of the measures climbed to a significant level. Nonetheless, in this study, the superiority of one type of education over another has not been shown. Previously conducted studies have also shown that in relation to both education types, the difference with respect to posttest mean scores of the scale was not statistically significant. pattern and applied to nurses in the United Arab Emirates tested a variety of education methods were tested, and no significant difference was observed between the groups receiving education (30). In research by Khatony et al. (2009), nurses were trained about AIDS via web education and face-to-face education techniques, and no significant difference existed between the two groups (31). Likewise, in Chan and colleagues' research among nursing students, web-based and face-to-face education methods were implemented, and after the training no statistical difference was observed between the groups (32).

In research by Aydın Avcı and Gözüm (2009), the effects of two types of training on the early diagnosis of breast cancer were investigated with respect to their influence on the beliefs and behaviors of teachers regarding breast cancer screening (33). In their study, the first group was trained via viewing a video, and the second group was trained via explanation on a model, a demonstration, and an application. In the assessment conducted after three months of education, there was a similar level of increase in both groups' knowledge, beliefs, and behaviors related to breast cancer screening.

Consequently, to increase the awareness of hypertension patients and to ensure that they are responsible for their own health, including compliance with medication and follow-up appointments, adaptation to healthy lifestyle behaviors, etc., various nursing interventions should be considered, such as nationwide training programs on health literacy, increased community awareness about nutrition, stress management, and exercise via media to ensure the prevention of hypertension and increase the self-efficacy of individuals, and awareness-raising programs on hypertension and health literacy can be prepared by using the web education method. 


\section{References}

1. World Health Organization. Hypertension, 2020. Available from: https://www.who.int/health-topics/hypert ension/\#tab=tab_1

2. Turkish Cardiology Association, PatenT. Available from: http://www.tkd.org.tr/pages.asp?pg=406

3. Rader S, Dorner TE, Schoberberger R, Wolf $H$. Effects of a web-based follow-up intervention on self-efficacy in obesity treatment for women. Wien Klin Wochenschr. 2017;129:472-81.

4. Bahari G, Scafide K, Krall J, Mallinson RK, Weinstein AA. Mediating role of self-efficacy in the relationship between family social support and hypertension self-care behaviours: A cross-sectional study of Saudi men with hypertension. International journal of nursing practice. 2019;25(6):1-8.

5. Mert K, Kadıoğlu H, Aksayan S. Validity and Reliability of The Self-Efficacy Scale-Child's Form. Kocaeli Medical Journal. 2018;7:135-9.

6. Çopurlar KC, Kartal M. What is Health Literacy? How to measure it? Why is it important? TJFMPC. 2016;10(1):42-7.

7. Kim MT, Song HJ, Han HR, Song Y, Nam S, Nguyen TH, et al. Development and validation of the high blood pressure-focused health literacy scale. Patient Educ Couns. 2012;87(2):165-70. doi: 10.1016/j.pec.2011.09.005.

8. Parker RM, Wolf MS, Kirsch I. Preparing for an epidemic of limited health literacy: weathering the perfect storm. Journal of General Internal Medicine. 2008;23:1273-6.

9. Demir Y, Gözüm S. New Approaches In Health Education; Web Based Health Education. DEUHYO ED, 2011;4(4):196-203.

10. O'Neil CA, Fisher CA, Newbold SK. Devoloping Online Learning Enviroments in Nursing Education. 2. Baskı. New York Springer Publishing Company. 2009;1-15:83-97.
11. Suka M, Odajima $T$, Kasai $M$, Igarashi $A$, Ishikawa H, Kusama M. The 14-item health literacy scale for Japanese adults (HLS-14). Environ Health Prev Med. 2013. doi:10.1007/s12199-013-0340-z.

12. Türkoğlu N, Kıııç D. Sağlık Okuryazarlığı Ölçeği'nin Türkçeye Uyarlanması: Geçerlilik ve Güvenilirlik Çalışması. Anadolu Hemşirelik ve Sağlık Bilimleri Dergisi, $\quad 2021 ; 24(1): 25-33$. doi:10.17049/ataunihem.662054.

13. Han HR, Lee H, Commodore-Mensah Y, Kim M. Development and validation of the Hypertension Self-care Profile: a practical tool to measure hypertension self-care. J Cardiovasc Nurs. $2014 ; 29$ ( 3 ): E 11 - 20 . doi:10.1097/JCN.0b013e3182a3fd46.

14. Türkoğlu N, Kılıç D. Turkish Reliability and Validity Study of the Hypertension Self-Efficacy Scale. Paper presented at the 18. ISPOG Congress, 2016b, Malaga, Ispanya.

15. Lenth $R$. Java applets for power andsample size. 2014. Available from: http://home-page.stat.uiowa.edu/ rlenth/ Powerl

16. Hacıalialioğlu, N. Teaching, Learning and Education in Nursing. 2011, Ankara: Nobel Medical Publishing

17. Julie $M$, Cooper BS, Marguerite $R$, Davenport BA, Kriya K, Gaillard BS. Health Literacy in Practice Program Evaluation. Kalamazoo, MI: Western Michigan University; 2011. pp. 1-156.

18. Kandula NR, Nsiah-Kumi PA., Makoul G., Sager J., Zei CP., Glass S., et al. The relationship between health literacy and knowledge improvement after a multimedia type 2 diabetes education program. Patient Educ Couns. 2009;75:321-7.

19. Bayati T, Dehghan A, Bonyadi F, Bazrafkan L. Investigating the effect of education on health literacy and its relation to health-promoting behaviors in health center. Journal of education and 
health promotion. 2018;7:127. doi:10.4103/jehp.jehp_65_18.

20. Altsitsiadis $E$, Undheim $T$, De Vries $E$, Hinrichs B, Stockfleth E, Trakatelli $M$. Health literacy, sunscreen and sunbed use: an uneasy association. $\mathrm{Br} J$ Dermatol. 2012;167(Suppl 2):14-21.

21. Cho Y, Lee SY, Arozullah AM, Crittenden $K S$. Effects of health literacy on health status and health service utilization amongst the elderly. Soc Sci Med. 2008;66:1809-16.

22. Pagan JA, Brown CJ, Asch DA, Armstrong K, Bastida E, Guerra C. Health literacy and breast cancer screening among Mexican American women in South Texas. J Cancer Educ. 2012;27(1):132-7.

23. McCleary-Jones V. Health Literacy and Its Association with Diabetes Knowledge, Self-Efficacy and Disease Self-Management Among African Americans with Diabetes Mellitus. The ABNF Journal. 2011:25-32.

24. Olgun N, Altun ZA. Effects of Education Based on Health Belief Model on Nursing Implication in Patients with Diabetes. University of Health Sciences Journal of Nursing. 2012;19(2):46-57.

25. Gleeson-Kreig JM. Self-monitoring of physical activity: effects on self-efficacy and behavior in people with type 2 diabetes. Diabetes Educ. 2006;32(1):69-77. doi: 10.1177/0145721705284285.

26. Kim CG, Park HA. Development and evaluation of a web-based education program to prevent secondary stroke. J Korean Acad Nurs. 2011;41(1):47-60. doi: 10.4040/jkan.2011.41.1.47.

27. Cingil D, Delen S, Aksuoğlu A. Evaluation of compliance and level of knowledge of patients with hypertension living in Karaman city center, Turkey. Archives of the Turkish Society of Cardiology.
2009;37(8):551-6.

28. Wei MH, Chen XZ, Zhan XX, Zhang ZX, Yu SJ, Yan WR. The effect of a web-based training for improving primary health care providers' knowledge about diabetes mellitus management in rural China: A pre-post intervention study. PLoS ONE. 2019;14(9):e0222930. Available from: https://doi.org/ 10.1371/journal.pone.0222930

29. Horiuchi S, Yaju Y, Koyo M, Sakyo Y, Nakayama K. Evaluation of a web-based graduate continuing nursing education program in Japan: $A$ randomized controlled trial. Nurse education today. 2009;29(2):140-9.

30. Salim N.A., Tuffah M.G., Brant J.M. Impact a pain management program on nurses' knowledge and attitude toward pain in United Arab Emirates: Experimental-four Solomon group design. Applied Nursing Research. 2020;15:13-14.

31. Khatony A, Nayery ND, Ahmadi F, Haghani $H$, Vehvilainen-Julkunen $K$. The effectiveness of web-based and face-to-face continuing education methods on nurses' knowledge about AIDS: a comparative study. BMC Med Educ. 2009; 10;9:41. doi: 10.1186/1472-6920-9-41.

32. Chan AW, Chair S, Wing-Hung Sit J, Wong EM, Lee DT, Fung OW. Case-Based Web Learning Versus Face-to-Face Learning: A Mixed-Method Study on University Nursing Students. The Journal of Nursing Research. 2016;24(1):31-40.

33. Avcı IA, Gozum S. Comparison of two different educational methods on teachers' knowledge, beliefs and behaviors regarding breast cancer screening. European Journal of Oncology Nursing. 2009;13(2):94-10. 